\title{
Grand challenges for cheminformatics
} David J Wild

\author{
Address: Editor-in-Chief, Journal of Cheminformatics, Indiana University School of Informatics, Bloomington, IN 47408, USA \\ Email: David J Wild - djwild@indiana.edu
}

Published: 17 March 2009

Journal of Cheminformatics 2009, I:I doi:10.1 I86/I758-2946-I-I

This article is available from: http://www.jcheminf.com/content/I/I/I

(c) 2009 Wild; licensee BioMed Central Ltd.

This is an Open Access article distributed under the terms of the Creative Commons Attribution License (http://creativecommons.org/licenses/by/2.0), which permits unrestricted use, distribution, and reproduction in any medium, provided the original work is properly cited.

\section{Editorial}

Welcome to the Journal of Cheminformatics. We are proud to be associated with a field that has a history longer than most applied computational disciplines; that has elegantly solved so many basic (and not so basic) problems; that has a reputation for intellectual rigor and goodnaturedness; that has hundreds of scholarly articles published; and that has impacted fields as diverse as drug discovery, library science and database searching. Every time an HIV patient takes a life-saving protease inhibitor, a synthetic chemist finds a needed journal article through a substructure search, or a medicinal chemist finds a new, promising set of compounds through a virtual screening experiment, they have good reason to thank the practitioners of the field we now call cheminformatics.

But therein lies a problem. We have impacted a diverse group of people and domains that defy a single categorization. We have done so with a small, scattered academic presence in very different environments (current cheminformaticians sit with various levels of comfort in Information Studies, Informatics, Computer Science, Chemistry, and Pharmacy departments among others). We only settled on a name for the field less than a decade ago, and we still struggle with its spelling. Much research has been carried out in pharmaceutical companies or with industry support, so is not as visible or accessible as comparable research in related fields such as bioinformatics. Unlike biology, academic chemistry traditionally has a much different scope than industrial and pharmaceutical chemistry.

So are we all about Library \& Information Science or Computational Drug Discovery? Is our work theoretical or pragmatic? Are our "customers" biologists or chemists?
Received: 6 March 2009

Accepted: 17 March 2009 
discovery research is carried out in academia, institutes and small companies, and solutions will require pieces from cheminformatics, bioinformatics and other disciplines, cheminformatics knowledge and tools should be made as widely available as possible.

\section{Green chemistry \& global warming}

Global warming and preserving the environment will be one of the biggest challenges for mankind this century. Fundamental to this will be finding chemicals which are less polluting or less toxic to the environment, or improving chemical use to minimize environmental impact (e.g. in petrochemicals). Cheminformatics already has much to offer through computational toxicology and predictive modeling.

\section{Understanding life from a chemical perspective}

Chemicals are being found to be increasingly important in cellular functions, for example through small molecule modulators and epigenetics. This has led to fields such as chemical biology, and more recently systems chemistry [1] and systems chemical biology [2], which seek to understand biological systems from a chemistry perspective. Integration of cheminformatics and bioinformatics methods will be key to this.

\section{Enabling the network of the world's chemical and biological information to be accessible and interpretable} We have seen huge leaps forward in the provision of freely accessible chemical databases such as PubChem [3] and ChemSpider [4]. A wealth of information is buried in these databases as well as many other related sources. Increasingly, this information is linked to biological information (such as targets, genes, experiments) and scholarly or informal publications, which opens up huge possibilities for data mining. Cheminformatics could potentially make all of this information very useful.

But of course these are just our thoughts. We need a discussion about priorities, and we need high quality research to point us in the right direction. Our aim in launching the Journal of Cheminformatics is to be a small but significant part in this process. Our name reflects our commitment to cheminformatics as a distinct discipline. Because we are an Open Access journal, our published work is immediately accessible through the web in a form which encourages propagation into other disciplines (such as being referenced in blog entries). We stand on the shoulders of BioMed Central, which contains some of the most highly cited journals in related fields such as Bioinformatics. We are committed to publishing only the highest quality research and insightful opinion that is most relevant to $21^{\text {st }}$ century science.
So welcome to the journal. In an editorial, we have the luxury of airing grand ideas but they may only be realized through the hard work of authors committed to this vision. So we thank the authors of articles already contributed, and we encourage you to help make the Journal of Cheminformatics a vibrant continuation into the $21^{\text {st }}$ century of a very important discipline.

\section{References}

I. Ludlow RF, Otto S: Systems chemistry. Chem Soc Rev 2008, 37:10I-108.

2. Oprea TI, Tropsha A, Faulon J, Rintoul MD: Systems chemical biology. Nat Chem Biol 2007, 3:447-450.

3. PubChem [http://pubchem.ncbi.nlm.nih.gov/]

4. Chemspider [http://www.chemspider.com/]

\footnotetext{
Publish with ChemistryCentral and every scientist can read your work free of charge

"Open access provides opportunities to our colleagues in other parts of the globe, by allowing anyone to view the content free of charge." W. Jeffery Hurst, The Hershey Company.

- available free of charge to the entire scientific community

- peer reviewed and published immediately upon acceptance

- cited in PubMed and archived on PubMed Central

- yours - you keep the copyright

Submit your manuscript here:

http://www.chemistrycentral.com/manuscript/

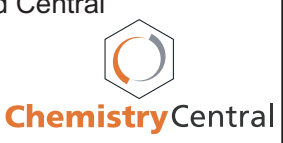

